\title{
The Americans with Disabilities Act: Accommodation in Ohio
}

\section{Scott A. Carpenter}

The Americans with Disabilities Act (Public Law 101-366) was signed into law on July 26, 1990, and took effect on January 26, 1992. This law, the most sweeping civil rights legislation since the 1964 Civil Rights Act and the 1973 Rehabilitation Act, has far-reaching ramifications for libraries. This study took a census of Ohio's 134 college and university libraries. A survey instrument obtained data on the types of accommodations that have been made in Title II (public), Title III (private), and Title IV (communication services and auxiliary aids) with respect to: access; auxiliary aids and services; rest room facilities; signage; and staff and policymaking. Hypotheses regarding the effects of library characteristics such as type of institution, new/old building, single/multistoried building, and physically disabled staff were tested.

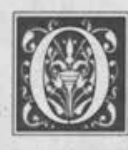

n July 26, 1990, President George Bush enacted the Americans with Disabilities Act (ADA) as Public Law 101336. The act was designed to provide comprehensive civil rights protection to individuals with disabilities in the areas of: employment, public accommodations, state and local government services, and telecommunications.

The ADA gives civil rights protection to the estimated 20 percent of the population with disabilities with respect to discrimination that is analogous to those protections provided individuals on the basis of race, color, national origin, sex, and religion. In doing so, it combines elements drawn principally from two key civil rights statutes: the Civil Rights Act of 1964, and Title V of the Rehabilitation Act of $1973 .{ }^{1}$ On July 26, 1991, the Department of Justice (DOJ), the imple- menting agency for both Title II and Title III of ADA, issued regulations and interpretive guidelines.

The ADA is divided into four parts: Title I; Title II; Title III; and Title IV. Title I is a federal antidiscrimination statute designed to remove barriers that prevent qualified individuals with disabilities from enjoying the same employment opportunities that are available to persons without disabilities. ${ }^{2}$ Title II prohibits public entities from discriminating on the basis of disability in services, programs, or activities. This prohibition applies to all state and local governments. It extends the prohibition of discrimination in federally assisted programs established by section 504 of the Rehabilitation Act of 1973 to all activities of state and local governments, including those that do not receive federal financial assistance. ${ }^{3}$ Title III prohibits discrimination on the basis of 
disability by private entities in places of public accommodation. It requires that all new places of public accommodation and commercial facilities be designed and constructed so as to be readily accessible to, and usable by, persons with disabilities. Also, courses for examinations related to licensing or certification for professional and trade purposes are required to be accessible to persons with disabilities. ${ }^{4}$ Title IV addresses the area of providing communication services and auxiliary aids.

Passage of the ADA has resulted in changes that affect all places of public accommodation, including libraries. Although the ADA does not set rules for compliance, it does provide guidelines for organizations and institutions to follow. These guidelines state that Title II service providers (e.g., public colleges or universities) and Title III service providers (private colleges or universities) make "reasonable accommodations" for persons with disabilities and make "readily achievable modifications" to accommodate persons with disabilities.

Since the ADA took effect on January 26, 1992, libraries, as public entities, have been required to take action on these guidelines. However, what is meant by "reasonable accommodations" and "readily achievable accommodations" is a point of controversy and confusion. The purpose of this research study is to determine the types of reasonable and readily achievable accommodations libraries have made in the areas of: access, auxiliary aids and services, rest room facilities, signage, and staff and policymaking by conducting a survey of the 134 college and university libraries in Ohio.

For this study, "ADA Guidelines" for Title II (public entities), Title III (private entities) and Title IV (communication services and auxiliary aids) were used. Title I (employment) was not included as a part of this study. The data gathered in this study were then analyzed to gain a better understanding of the extent to which libraries have made accommodations for persons with disabilities; and to the degree that they have not been met, to offer preliminary observations as to potential correlates of this nonaccommodation.

\section{Literature Review}

A great deal of writing has focused on helping libraries and other entities understand the ADA and helping develop prescriptions for compliance with it. Some of these previous efforts have consisted of question-and-answer forums to help librarians focus on the various aspects of their facilities that require attention. ${ }^{5}$ Other works have described the ADA, detailing its different facets and their applicability to public and private academic libraries. ${ }^{6}$ In addition, the expertise of lawyers also has been utilized to understand more completely the ramifications of the ADA and to offer suggestions of ways to comply. ${ }^{7}$ Other work has focused on highlighting the work of a given institution in accommodating persons with disabilities. ${ }^{8}$

Most of the literature pertaining directly to the responsibility of libraries in complying with the ADA has focused on explaining the law and providing prescriptions for more complete compliance. Another example of this prescription is the work of Melanie J. Norton, who examined adapting bibliographic instruction (BI) for deaf or hearing-impaired patrons. ${ }^{9}$ Norton outlines the adaptations that are necessary (e.g., special BI classes, increased use of written as opposed to orally presented materials) to adapt to the needs of deaf and hearing-impaired patrons. Despite these studies, recent bibliographies indicate that the majority of work in library science on ADA compliance remains in a formative stage, and has not progressed to evaluating ADA compliance and influence. ${ }^{10}$

The author's research will help address these deficits in the study of the effect of the ADA on libraries. However, 
there has been work in other areas of ADA compliance apart from that directly affecting libraries. In the author's study of the degree of accommodation with the ADA by college and university libraries in Ohio, as well as the factors that may be associated with this compliance, he can draw on some of the aspects of these research studies. These aspects of previous work include: methodology, intervening factors affecting compliance, and statistical analysis.

The dominant methodology for assessing the degree of compliance or of accommodation is survey methodology. This study, rather than measuring compliance (which involves a strict legalistic interpretation of the ADA), focuses on accommodation. That is, the author is investigating the more minimal steps libraries have taken toward full compliance with the ADA. Surveys have been used to measure the extent to which primary and secondary schools are complying, as well as to measure compliance from universities in general-beyond the role of the library. ${ }^{11}$ In keeping with this prior research, the author utilized a survey to collect data on accommodation with the ADA by college and university libraries in Ohio.

Other studies have used different populations for their respondent groups. In his study, William Mark Fornadel surveys the ADA compliance officer at each public college or university throughout the United States. ${ }^{12}$ As explained below, surveying the compliance officer was considered for this project. However, this survey population was ruled out, in part because available resources limit the research to Ohio and in part because it is not known which colleges and universities in Ohio have compliance officers.

Not only has previous work illustrated that survey methodology is appropriate for the author's research, but it also provides insights into some of the factors that may affect the libraries' degree of accom- modation. In general, the two most-cited barriers to full compliance are the costs involved and the size of the institution. In examining the extent to which school systems (primary and secondary) in $\mathrm{Ne}-$ braska are complying with the ADA, Joseph Vincent Reinert found that the size of the school affects the degree of compliance present. ${ }^{13}$ Scott Jaschik indicates, in exploring college and university administrators' attitudes toward the ADA and its effect on their institutions, that cost is a

\section{the two most-cited barriers to full compliance are the costs involved and the size of the institution.}

key factor in compliance. ${ }^{14}$ These administrators see the cost of removing the barriers to compliance as an important element in the decision-making process as they deliberate on their reactions to the ADA.

Finally, research to date sheds light on appropriate statistics to utilize in analyzing the data. In general, when assessing the extent to which entities have complied with the ADA, descriptive statistics (e.g., mean, median) are most often used. However, in exploring the various factors that may co-vary with compliance, inferential statistics measuring association are used (e.g., Chi-square and difference of means). These statistics helped the researchers assess whether factors such as size of institution and/or cost of barrier removal are associated with compliance in a statistically significant manner.

In summary, this review of the literature has shown that research on the impact of the ADA on libraries is limited to writings explaining the law and the responsibilities of libraries in complying. The relatively scarce work describing compliance does not go far beyond case studies of a single school's compliance in a few areas of the library. There has been more work done in areas beyond 
library science in measuring compliance and enumerating the factors that may affect it. This work points to: the applicability of survey methodology; the possibility of costs and size of institution acting on the degree of compliance; and the use of several statistics in disentangling the effects.

\section{Research Objectives}

The purpose of this research study is to compare the ways the 134 college and university libraries in Ohio have made accommodations to persons with disabilities. Several different categories of libraries' accommodations were examined to determine the types of reasonable and readily achievable accommodations that have been made, including access, auxiliary aids and services, rest room facilities, signage, and staff and policy-making.

This research study describes the extent to which the 134 college and university libraries in Ohio are meeting the

\section{Most likely, buildings constructed after the ADA was enacted have made accommodations to persons with disabilities.}

minimum standards of compliance with the ADA and to examine characteristics of the libraries that might cause differences in accommodation. First, in measuring the minimum standards of compliance, this study measures the extent to which libraries have achieved the "easiest" accommodations. The survey instrument has measures of compliance adapted from The Americans with Disabilities Act: Title III Technical Assistance Manual. ${ }^{15}$ This publication indicates those steps toward full compliance with the ADA that should be readily achievable. The scope of this research study covers all these areas of accommodation.

Second, beyond describing the reality of libraries' adaption to the needs of per- sons with disabilities, the different characteristics of the libraries that might be associated with differences in accommodation were examined. Based on personal experience, the author suspects that the degree to which all college and university libraries in Ohio provide accommodation varies across libraries. This research study is an initial attempt to examine different characteristics of the libraries that might co-vary with accommodation.

There are several factors that could affect meeting the minimum standards of accommodation: public versus private institutions; whether the library was constructed before or after the ADA was enacted; the extent to which the physical facilities exacerbate accessibility issues; and whether there are any disabled library staff. Based on personal experience, the author expects that private colleges and universities, which can control somewhat the types of students they admit, will be less accommodating to persons with physical disabilities. Public institutions, whose funding is primarily out of public money, may well feel a greater need to be more ADA compliant than do private institutions. Most likely, buildings constructed after the ADA was enacted have made accommodations to persons with disabilities. Also, where the physical facilities augment accessibility problems (e.g., where there are multiple stories in buildings), there has been a greater likelihood of accommodation. Finally, it is likely that a library that has accommodated a staff person with a physical disability also will accommodate a patron with a physical disability. This study attempted to confirm that these factors affect minimum standards of accommodation across college and university libraries in Ohio by using the following hypotheses:

$\mathrm{H}_{1}$ Public college and university libraries will be more likely to accommodate patrons with physical disabilities than private college and university libraries. 
$\mathrm{H}_{2}$ Libraries built after the ADA was passed will be more likely to make accommodations to persons with disabilities.

$\mathrm{H}_{3}$ Multistoried libraries will be more likely than single-storied libraries to make accommodations to persons with disabilities.

$\mathrm{H}_{4}$ College or university libraries that have physically disabled staff will be more likely to accommodate patrons with physical disabilities.

Accommodation, institution type, age of building, number of stories, and existence of physically disabled staff are measured with questions from the survey instrument. To ensure that these measures address accommodation, these questions were drawn from The Americans with Disabilities Act: Title III Technical Assistance Manual. ${ }^{16}$

\section{Methodology}

The population for this study consists of the college and university library directors from the state of Ohio as determined by the Directory of Ohio Libraries, 1995 edition. ${ }^{17}$ A census of college and university library directors in the state of Ohio was conducted to determine the degree to which libraries accommodate persons with disabilities and how the characteristics of the libraries and their colleges or universities affect these accommodations. When the Directory of Ohio Libraries listed head librarian instead of library director, the head librarians were surveyed.

Library directors were selected because they would be able to provide the most complete information on all aspects of their respective libraries under study. Originally, the author had wanted to select the librarian in charge of ADA compliance, but not every library has a person specifically designated for this. For the sake of consistency, the director of each library was chosen. The ADA bill is complex, and even if different library individuals or committees are in place to discuss aspects of library services (i.e., reference, circulation), these individuals or committees would likely convey their conclusions to the library director.

The entire population of Ohio college and university library directors was used for this study. In this respect, this study takes a census of all 134 college and university libraries in Ohio. Within the $\mathrm{Di}$ rectory of Ohio Libraries, there are actually 136 libraries. However, Denison University was omitted from this study, given its involvement in the circulation of the materials. Also, one respondent was director of two libraries, which were in a joint facility. Thus, the total number of libraries surveyed is 134 . The response rate is quite respectable; ninety-seven libraries $(72.4 \%)$ completed the survey.

\section{Design and Procedures}

The survey instrument was printed on light grey paper in an effort to make it stand out from other documents received by the library directors. That color is pleasing to the eye and still allows the printed text to be read easily. The survey instrument also was reduced and made into a booklet, approximately 5.5 inches by 8.5 inches, or the size of a half sheet of paper. This gives the illusion of a much smaller survey. Finally, the survey was organized into different sections of questions: access, auxiliary aids and services, rest room facilities, signage, and staff and policymaking. With the survey organized into sections, the respondent does not feel overwhelmed by answering the 91 questions. Along with dividing the survey into sections, question branching also was used. This prevents the respondent from answering irrelevant questions. This also means that the respondent did not necessarily answer all the survey questions.

The survey instrument for this study was mailed on October 1, 1995, along with a cover letter. Included in the mailing was a stamped, self-addressed return envelope to help increase the response rate. To help reduce nonresponse bias, a 
second cover letter and questionnaire were mailed, two and a half weeks after the first mailing (October 18, 1995), along with a stamped, self-addressed return envelope, to those who had not yet responded. The questionnaire was identical to the first one mailed, and the cover letter reminded the respondent that the first letter and questionnaire were mailed on October 1, 1995. If after these two attempts a response was not received, it was assumed that the respondent chose not to participate in the study.

To maintain confidentiality, the only identifier was a coding number on the back of the envelope. The code was on the return envelope so as to minimize its presence. If a second questionnaire was sent in an attempt to persuade a respondent to participate, the same coding number was used. Respondents were told in the cover letter that their responses would be confidential and used for research purposes only and that their names would never be used or associated with the results in any way.

\section{Data Analysis}

\section{A Profile of Accommodation}

The extent to which college and university libraries in Ohio have made accommodations to persons with disabilities varies considerably, both in terms of the kinds of changes they have made and in the degree of their efforts. This section details the amount of accommodation made in each of the six different areas (access, auxiliary aids and services, rest room facilities, signage, and staff and policymaking).

To facilitate discussion of the extent to which libraries have made accommodations to persons with disabilities, questions within each of the categories of accommodation have been collapsed into scales. Table 1 details, within each of the six categories of accommodation, which questions comprise each of the ten scales.

\begin{tabular}{|c|c|c|c|c|}
\hline \multicolumn{5}{|c|}{$\begin{array}{c}\text { TABLE } 1 \\
\text { Accommodation Scales }\end{array}$} \\
\hline & Scale Name & Description & Mean & Median \\
\hline Access & ACCESS & Accessibility to the building & .662 & .800 \\
\hline \multirow[t]{5}{*}{ Auxiliary Aids } & AUDNET & $\begin{array}{l}\text { Availability of audio forms } \\
\text { of Internet services }\end{array}$ & .079 & .000 \\
\hline & TDD & Availability of TDD services & .034 & .000 \\
\hline & READ & $\begin{array}{l}\text { Availability of manual } \\
\text { magnification devices }\end{array}$ & .242 & .000 \\
\hline & MAGNIFY & $\begin{array}{l}\text { Availability of electronic } \\
\text { magnification devices }\end{array}$ & .214 & .000 \\
\hline & PHOTO & $\begin{array}{l}\text { Availability of photocopying } \\
\text { and paging services }\end{array}$ & .819 & 1.00 \\
\hline Restrooms & RESTROOM & Accessibility of restroom facilities & .420 & .500 \\
\hline Signage & SIGN & Accessibility of library signage & .286 & .200 \\
\hline Staff & STAFF & $\begin{array}{l}\text { Existence of staff for } \\
\text { persons with disabilities }\end{array}$ & .353 & .400 \\
\hline Policy & POLICY & $\begin{array}{l}\text { Existence of policymaking sensitive } \\
\text { to persons with disabilities }\end{array}$ & .511 & .667 \\
\hline
\end{tabular}


Factor analysis was used to help guide the choice of question grouping. That is, within each of the six categories, questions that belonged together substantively were entered into a factor analysis. After examining the solution, the author made final judgments as to which items belonged together in a scale. As a final check on the reliability of the scale, a Cronbach's Alpha statistic was generated for each of the ten scales. For each, the alpha attained acceptable levels. The Cronbach's Alpha statistic measures the extent to which individual items in unidimensional scales belong in the same scale. Using this tool, researchers can examine whether each component adds to, or detracts from, the reliability of the scale itself.

Once the choice of items in each scale was made, the author generated the scale. Because the survey questions are bivariate, each one eliciting a positive or "yes" response received one point. The points were totaled across all the items in the scale and then divided by the total number of items in the scale. For each of the ten scales, this results in scores that are proportions of accommodation rendered. That is, each of the scores varies from 0 to 1.0 , where 1.0 indicates the highest level of accommodation.

Table 1 also provides information about the average (mean) score for each of the scales as well as the median (middle-most) score in order for a "typical" library to be described. Missing data were excluded listwise; if a respondent did not answer a question among those in a scale, the respondent was removed from the calculation of that particular scale.

\section{Access}

Among the six different categories of accommodation, the greatest accommodation generally made is in the area of physical access. Of the ten scales created to measure accommodation efforts across the six categories, the average library scored .662 on the access scale. Table 1 compares the mean scores for each of the ten accommodation scales. That is, this table represents how the average library scored on each of the ten measures. (Recall from the previous section that these ten measures represent accommodation across the six different categories.)

The relatively high mean on the access scale is indicative of the 30 percent of all libraries that answered yes to three of the five items in the access scale, and the 54 percent of libraries that said yes to four out of the five items. (This access score is composed largely of questions dealing with access to the building itself, in terms of ramps, parking spaces, and curb cuts.)

In contrast to the relatively large portion of libraries that have made access to the building easier, responses to three specific items stood out as overwhelmingly negative: the use of levers for exterior doors; levers for interior doors; and existing doors being widened with offset hinges. A great majority of respondents said their library did not have these features $(71 \%, 77 \%$, and $77 \%$, respectively).

Access to public phones was a bit more readily available to persons with disabilities. Almost half (49\%) of the respondents reported that they had lowered at least one telephone to make it accessible to persons with disabilities.

\section{Auxiliary Aids and Services}

With the exception of access to photocopying services, auxiliary aids and services were the least accessible to persons with disabilities. As table 1 demonstrates, four out of the five scales measuring compliance in auxiliary aids and services had the lowest average scale scores (Telecommunications Device for the Deaf [TDD] availability, audio access to Internet services, manual magnification devices, and electronic magnification devices).

The average library had only one of the three items that comprise the TDD scale, as reflected in the mean of .034 . The largest percentage ( $94 \%$ ) had none. 
Also, most libraries have neither policies to purchase closed-captioned videotapes $(86 \%)$ nor closed-captioned decoders $(90 \%)$.

Similarly, 81 percent of all libraries made no Internet services available in audio form. Ninety-six percent had neither collections of large-print books, nor did they provide audiocassette copies of printed books from the collection.

Libraries provided relatively greater access to magnification aids (both manual and electronic). In terms of access to manual magnification devices, the majority of libraries had neither item in the scale, but a fair percentage $(37 \%)$ had one. The slightly higher average score on the scale measuring electronic magnification device availability belies that a substantial percentage (13\%) answered yes to both items in that scale.

Most of the libraries (65\%) responded that bibliographic instruction is not taught in special computerized classrooms. Also, 96 percent do not have a special disabilities services room.

Just over half $(51 \%)$ of the libraries did not have workstations established for persons with disabilities. However, of those that did respond that they had such stations, an overwhelming percentage $(84 \%)$ said that persons with disabilities have first priority to use the stations.

Access to photocopying and/or paging services was the highest across all ten scales. A clear majority $(73 \%)$ responded that policy stipulated that the reserves and reference staffs photocopy and page materials for persons with disabilities.

\section{Rest Room Facilities}

In general, libraries showed moderate accessibility to rest room facilities for persons with disabilities. The typical library had four out of the five items that comprise the rest room scale, as represented by the mean rest room score of .420 . Eleven percent had all eight of the items that are captured by this measure.
However, full-length mirrors were less common. Libraries responded that 87 percent of men's rest rooms and 69 percent of women's rest rooms did not have these features.

Also, many sink pipes have not been insulated to protect persons with disabilities. For example, the heat generated from hot water pipes poses a risk of burns to people in wheelchairs. Responses indicate that 85 percent of men's rest rooms and 84 percent of women's rest rooms do not have insulated pipes.

Finally, most libraries have not put paper cups at inaccessible water fountains. Ninety-three percent responded that they had no such paper cup dispensers.

\section{Signage}

Directors also were asked a series of questions on the signs posted within the facility. Generally, signs were not made visible to persons with disabilities. The typical library responded that it had only one of the five items that comprise the signage scale, a mean score of .286. A quarter of the libraries (25\%) said they had none.

\section{Staff and Policymaking}

In general, libraries scored relatively high on both of the scales that measure the existence of staff geared toward persons with disabilities and the extent to which persons with disabilities have been taken into consideration in the policymaking process. As table 1 shows, typical libraries have two out of the five items that comprise the staff scale, a mean score of .353. Many (16\%) have three out of the five items.

A full 50 percent have two out of the three items in the policymaking scale. This suggests that, to a certain extent, the needs of persons with disabilities have been considered in making university and library policy. In fact, almost half the respondents $(48 \%)$ said the library was consulted before changes were made. 


\begin{tabular}{|lcc|}
\hline \multicolumn{3}{|c|}{$\begin{array}{c}\text { TABLE 2 } \\
\text { Staff with Disabilities }\end{array}$} \\
\hline \hline & Degreed & Nondegreed \\
\hline Sight & 2 & 1 \\
Hearing & 4 & 1 \\
Mobility & 6 & 9 \\
Acquisitions & 2 & 1 \\
Administration & 0 & 2 \\
Archives & 1 & 0 \\
Cataloging & 2 & 2 \\
Circulation & 2 & 1 \\
Government & 0 & 0 \\
$\quad$ Documents & & \\
Interlibrary Loan & 1 & 3 \\
Bibliographic & 2 & 0 \\
$\quad$ Instruction & & \\
Periodicals & 2 & 2 \\
Reference & 7 & 3 \\
Reserves & 2 & 1 \\
Other & 1 & 1 \\
\hline
\end{tabular}

Despite the degree of accessibility to the different areas and services within the libraries, few staff members (degreed or nondegreed) have disabilities. Table 2 displays these results. With regard to the degreed staff who have disabilities, most are disabled in mobility (six cases), while some have hearing disabilities (four cases). In contrast, all but two cases of nondegreed staff have mobility disabilities.

Table 2 also shows the distribution of staff members with disabilities across the various library departments. Within the ranks of the degreed staff with disabilities, most are in reference services. Among nondegreed staff, the distribution is more even. Three cases each are in interlibrary loan and reference; two cases each are in administration, cataloging, and periodicals.

In general, the previous descriptions indicate that there are some areas of the library in which there has been a fair degree of accommodation. Photocopying services and access to the buildings stand out in this regard. However, there are many other areas of the libraries where accessibility is not widely provided to persons with disabilities. Next, the author examined the extent to which the level of accommodation is differentiated by characteristics of the libraries.

\section{Hypotheses Testing \\ Type of Institution}

One of the hypotheses was that public institutions would be more likely than private institutions to provide accommodation to persons with disabilities. To test this proposition, a difference of means test was performed to see if the difference between these two groups' mean scores on each of the scales of accommodation is statistically significant.

Type of institution differentiated several of the scales. As table 3 shows, the availability of the following differed significantly between private and public institutions: audio Internet services, TDD services, manual magnification devices,

\begin{tabular}{|c|c|c|c|}
\hline Accom & $\begin{array}{l}\text { TABLE } \\
\text { modatior } \\
\text { f Institu }\end{array}$ & $\begin{array}{l}3 \\
\text { by Typ } \\
\text { ion }\end{array}$ & \\
\hline Scale & $\begin{array}{c}\text { Private } \\
\text { Mean }\end{array}$ & $\begin{array}{l}\text { Public } \\
\text { Mean }\end{array}$ & $\mathrm{t}^{*}$ \\
\hline ACCESS & .659 & .679 & .601 \\
\hline AUDNET** & .015 & .145 & .003 \\
\hline TDD** & .000 & .070 & .043 \\
\hline READ** & .136 & .354 & .003 \\
\hline MAGNIFY & .233 & .198 & .545 \\
\hline РнОТО & .830 & .796 & .625 \\
\hline REST & .390 & .483 & .295 \\
\hline SIGN** & .241 & .339 & .079 \\
\hline STAFF** & .265 & .449 & .001 \\
\hline POLICY** & .427 & .615 & .010 \\
\hline $\begin{array}{l}\text { * The t statistic } \\
\text { given relatio } \\
\text { between the } \\
\text { meaningful } \\
\text { there is a } 60 \\
\text { difference be } \\
\text { of private ins } \\
\text { is due to cha } \\
\text { ** Indicates stat }\end{array}$ & $\begin{array}{l}\text { assesses the } \\
\text { ship (in this } \\
\text { leans) is sta } \\
\text { mere chan } \\
\text { ercent chan } \\
\text { ween the m } \\
\text { itutions and } \\
\text { ce. } \\
\text { stically sign }\end{array}$ & $\begin{array}{l}\text { extent to } \\
\text { case the di } \\
\text { istically } \\
\text { e. For exar } \\
\text { ce that the } \\
\text { public inst } \\
\text { ificant diff }\end{array}$ & $\begin{array}{l}\text { hich a } \\
\text { ference } \\
\text { iple, } \\
\text { S score } \\
\text { tutions } \\
\text { rences. }\end{array}$ \\
\hline
\end{tabular}




\begin{tabular}{|lccc|}
\hline \multicolumn{4}{|c|}{$\begin{array}{c}\text { TABLE 4 } \\
\text { Accommodation by Age } \\
\text { of Building }\end{array}$} \\
\hline \hline Scale & $\begin{array}{c}\text { New Bldg } \\
\text { Mean }\end{array}$ & $\begin{array}{c}\text { Old Bldg } \\
\text { Mean }\end{array}$ & $\mathrm{t}$ \\
\hline ACCESS & .700 & .665 & .582 \\
AUDNET & .125 & .078 & .551 \\
TDD & .000 & .038 & .589 \\
READ & .250 & .250 & 1.0 \\
MAGNIFY & .250 & .212 & .714 \\
PHOTO & .929 & .803 & .327 \\
REST & .542 & .422 & .423 \\
SIGN* & .550 & .276 & .028 \\
STAFF & .433 & .347 & .427 \\
POLICY & .444 & .515 & .675 \\
\hline * Indicates statistically significant differences. \\
\hline
\end{tabular}

signage, staffing, and policymaking. Across the board, the hypothesis was confirmed; public institutions were significantly more likely to provide these services than were private institutions.

\section{New/Old Building}

Another hypothesis is that newer buildings, especially ones built after the ADA was passed in 1992, would have a higher likelihood of providing disabilities services. However, there was much less evidence in support of this hypothesis. As can be seen from table 4, only the accessibility of library signage evidences any significant difference between old and new buildings.

\section{Single versus Multistoried Buildings}

Another hypothesis is that where the library structure provides greater challenge to some persons with disabilities, compliance will be greater. In this regard, one would expect multistoried buildings to show greater accommodation, especially in access to the building. As table 5 shows, there is some evidence to support this hypothesis. Access to the building varies significantly with whether the building has one or more floors; libraries in multistoried buildings have greater access. Also, at relaxed levels of statistical significance, accessibility of library signage also varies by single versus multistoried buildings. Again, multistoried buildings are more likely to have better compliance in sign accessibility.

\section{Staff with Disabilities}

The final hypothesis is that libraries that have staff members (degreed or nondegreed) with disabilities will be more likely to be more accommodating to patrons with disabilities. As table 6 demonstrates, there is limited evidence that this is the case. Only audio access to Internet services and accessibility of library signage are differentiated by having disabled staff or not. Even the difference between the groups on these scales is significant only at levels far below conventional levels.

In general, the greatest differentiating factor in whether libraries make accommodations for persons with disabilities is type of institution. The likelihood of public institutions showing greater compliance was stronger than for other potentially influencing factors and also had an impact across a greater portion of the different scale measures.

\begin{tabular}{|lccc|}
\hline \multicolumn{4}{|c|}{$\begin{array}{c}\text { TABLE 5 } \\
\text { Accommodation by } \\
\text { Number of Stories }\end{array}$} \\
\hline \hline Scale & 1 Floor & 1+ Floor & t \\
& Mean & Mean & \\
\hline ACCESS* & .590 & .687 & .034 \\
AUDNET & .121 & .061 & .206 \\
TDD & .063 & .023 & .291 \\
READ & .167 & .272 & .195 \\
MAGNIFY & .250 & .199 & .413 \\
PHOTO & .796 & .828 & .668 \\
REST & .456 & .407 & .622 \\
SIGN* & .226 & .310 & .160 \\
STAFF & .374 & .344 & .646 \\
POLICY & .556 & .496 & .485 \\
\hline *Indicates statistically significant differences. \\
\hline
\end{tabular}




\begin{tabular}{|lccc|}
\hline \multicolumn{4}{c|}{$\begin{array}{c}\text { TABLE 6 } \\
\text { Accommodation by Staff } \\
\text { with Disabilities }\end{array}$} \\
\hline \hline Scale & $\begin{array}{c}\text { No Disabled } \\
\text { Staff Mean }\end{array}$ & $\begin{array}{c}\text { Disabled } \\
\text { Staff Mean }\end{array}$ & $\mathrm{t}$ \\
\hline ACCESS & .667 & .648 & .683 \\
AUDNET* & .094 & .024 & .177 \\
TDD & .040 & .018 & .576 \\
READ & .237 & .262 & .775 \\
MAGNIFY & .200 & .262 & .371 \\
PHOTO & .833 & .763 & .399 \\
REST & .481 & .427 & .929 \\
SIGN* & .265 & .358 & .143 \\
STAFF & .357 & .338 & .784 \\
POLICY & .497 & .576 & .404 \\
\hline${ }^{*}$ Indicates statistically significant differences. \\
\hline
\end{tabular}

\section{Significance}

Although college and university libraries will continue to make strides in accommodating persons with disabilities, thus causing this research to be outdated quickly, the research is still important in that it provides a baseline by which other research studies can determine how rapidly changes are occurring.

A limitation of this research is that it considered only college and university libraries in Ohio. Further research needs to include investigation into accommodations made by other types of librariespublic, school, and special. One could suspect that the degree of accommodation across these types of libraries might vary.

In addition to concerns about including studies of other types of libraries, presumably libraries will continue to make their facilities more available. In this light, it will be important to reassess the de- gree to which they have complied with the ADA. A similar study to this one should be undertaken every three to five years.

Finally, this work helps us to understand accommodation to the ADA in Ohio only. In order to have a basis on which to compare Ohio to the rest of the country, it would be necessary to undertake similar studies in other states. In this way, we can know more precisely the adequacy of the job Ohio college and university libraries are doing.

This research study provides insight into how well Ohio college and university libraries have made accommodations for individuals with disabilities. The ADA indicates that approximately 20 percent of the population is recognized as having a disability. With college and university enrollment declining and more individuals with disabilities being mainstreamed into society, the number of college and university students with disabilities will fill in this declining

\section{A limitation of this research is that it considered only college and university libraries in Ohio.}

\begin{abstract}
"traditional" student population. This study provides accommodation statistics for the 134 Ohio college and university libraries in terms of access, auxiliary aids and services, rest room facilities, signage, and staff and policymaking. Although libraries in Ohio have made inroads in ADA accommodations (especially in making access to physical facilities easier), much work remains.
\end{abstract}

Notes

1. U.S. Equal Employment Opportunity Commission and the U.S. Department of Justice, Americans with Disabilities Act Handbook (Washington, D.C.: Government Printing Office, 1991).

2. Ibid.

3. Ibid.

4. Ibid.

5. Michael G. Gunde, "Working with the Americans with Disabilities Act," Library Journal 
116 (Dec. 1991): 99-100; and "Working with the Americans with Disabilities Act: Part II," Library Journal 117 (May 1992): 41-42.

6. Nancy C. Pack and Donald D. Foos, "Library Compliance with the Americans with Disabilities Act," RQ 32 (winter 1992): 255--67.

7. Ty D. Laurie, "Libraries' Duties to Accommodate Their Patrons under the Americans with Disabilities Act," Library Administration \& Management 6 (fall 1992): 204-05; Richard T. Miller, "The Americans with Disabilities Act: Library Facility and Program Access under Titles II and III," Ohio Libraries 5 (Mar./Apr. 1992): 8-11.

8. John L. Jax and Theresa Muraski, "Library Services for Students with Disabilities at the University of Wisconsin-Stout," Journal of Academic Librarianship 19 (July 1993): 166-68.

9. Melanie J. Norton, "Effective Bibliographic Instruction for Deaf and Hearing-Impaired College Students," Library Trends 41 (summer 1992): 119-25.

10. Jessica Adams Bray, "The Americans with Disabilities Act of 1990: New Questions," RQ 31 (spring 1992): 315-24.

11. Joseph Vincent Reinert, "Nebraska School Districts: Coming into Compliance with the Americans with Disabilities Act (Disabilities)" (Ph.D. diss., Univ. of Nebraska-Lincoln, 1994); Jeffrey Carl Senge, "Print Accessibility for Print Disabled Students in the California State University System" (Ph.D. diss., California State Univ. -Fullerton, 1993); William Mark Fornadel, "The Implementation of Americans with Disabilities Act of 1990 in Public Higher Education: Organization, Compliance, and Concerns" (Ph.D. diss., Univ. of Virginia, 1994); Bobbie Beth Scoggins, "A Study to Develop Executive Guidelines for the Successful Implementation of the Americans with Disabilities Act in California Community Colleges (Disabilities, Compliance)" (Ph.D. diss., Pepperdine Univ., 1992).

12. Fornadel, "The Implementation of Americans with Disabilities Act of 1990."

13. Reinert, "Nebraska School Districts."

14. Scott Jaschik, "Backed by 1990 Law, People with Disabilities Press Demands on Colleges," Chronicle of Higher Education 39 (Feb. 1993): A26.

15. U.S. Department of Justice, Civil Rights Division, Office on the Americans with Disabilities Act, The Americans with Disabilities Act: Title III Technical Assistance Manual (Washington, D.C.: Government Printing Office, 1992).

16. Ibid.

17. Directory of Ohio LIbraries 1995 (Columbus: The State Library of Ohio, 1995).

\section{Service Quafity in Academic Libraries}

by Peter Hernon, Simmons College, \& Ellen Altman

Cloth: 1-56750- 209-1 / \$52.50 Paper: 1-56750-210-5 / \$24.50

This book examines service quality, identifies its essential elements and discusses ways in which service quality can be assessed.
To place an order call: A6lex Publisfing at 201-767-8455 or send a fax to 201-767-6717 